\title{
Illegal trade and conservation requirements of freshwater turtles in Nanmao, Hainan Province, China
}

\author{
Gong Shiping, Wang Jichao, Shi Haitao, Song Riheng and Xu Rumei
}

\begin{abstract}
China has one of the world's most diverse freshwater turtle faunas but is also a major consumer of freshwater turtles. In the 1980s over-collecting, illegal trade and habitat destruction increased dramatically, pushing almost all Chinese turtles towards extinction. Despite the critical status of Chinese turtles little has been done to quantify and evaluate the impact of illegal activities on wild populations. We used a combination of market surveys and questionnaires to examine the illegal trade and conservation status of native freshwater turtles in Nanmao, Hainan Province, from February to August 2003. We found a total of 245 collected freshwater turtles comprising eight
\end{abstract}

species. These data indicate that Nanmao has a rich freshwater turtle fauna that is being affected heavily by illegal poaching. No effective measures have been taken to protect the few remaining wild turtle populations. The main factors that lead to illegal trade include the cultural belief that turtles are a viable food/medicine product, lack of conservation awareness, poaching of turtles as a supplement to income, and poor law enforcement. Possible conservation strategies are discussed.

Keywords China, conservation status, freshwater turtle, Hainan, illegal trade, poaching, threat.

\section{Introduction}

China has one of the world's richest freshwater turtle faunas. Since the 1980s, however, illegal trade, overcollecting and habitat destruction have been threatening many freshwater turtle species (Zhao, 1998; Lau \& Shi, 2000). Much of this is driven by the fact that China is the major consumer of freshwater turtles (Ades et al., 2000; Compton, 2000; van Dijk, 2000). Although many turtle species are protected by CITES and China's Wild Animals Protection Law, they can be found in restaurants and food markets (DeBruin \& Artner, 1999; Gong, 2003; Gong et al., 2003a; Shi, 2004a, b; CITES, 2005; Gong et al., 2005a). The high market value of these turtles provides incentive for many farmers to become full-time turtle collectors (Lau \& Shi, 2000; Gong et al., 2003a).

Gong Shiping College of Life Sciences, Beijing Normal University, Beijing 100875, China; Department of Biology, Hainan Normal University, Haikou 571158, China; South China Institute of Endangered Animals, Guangzhou 510260, China.

Wang Jichao, Shi Haitao (Corresponding author) and Song Riheng Department of Biology, Hainan Normal University, Longkunnan Road No.99, Haikou 571158, China. E-mail haitao-shi@263.net

Xu Rumei College of Life Sciences, Beijing Normal University, Beijing 100875, China.

Received 25 May 2005. Revision requested 21 September 2005 Accepted 4 January 2006
Hainan Province, a subtropical island in the South China Sea, has 12 species of freshwater turtle (50\% of the non-marine turtle species in China; Zhang et al., 1998; Zhao et al., 2000; Parham et al., 2001; Dalton, 2003). The biodiversity of Hainan is of high conservation priority, although the island is also a site of rampant illegal turtle trade (Gong, 2003; Gong et al., 2003a, b, 2005a, b; Shi, $2004 a, b)$. Because of its secrecy it is difficult to quantify the impact of this trade, although this is crucial for assessing the status of turtle populations and determining appropriate conservation strategies.

In August 2002 we conducted a preliminary survey of the distribution and illegal trade of freshwater turtles in Hainan Province (Gong, 2003). From discussions with villagers we inferred that the freshwater turtle fauna of the area of Nanmao was relatively rich despite serious human impacts. To collect detailed data we surveyed illegal trade and collecting of freshwater turtles in Nanmao during February-August 2003. Our aims were to (1) determine the status of freshwater turtle populations, (2) clarify the status and causes of illegal trade and collecting, and (3) provide recommendations for conservation of these turtle species.

\section{Study area}

The region of Nanmao is located in the central mountains of Hainan Province at 200-1,200 m altitude (Fig. 1) and is inhabited by people of the Miao minority 


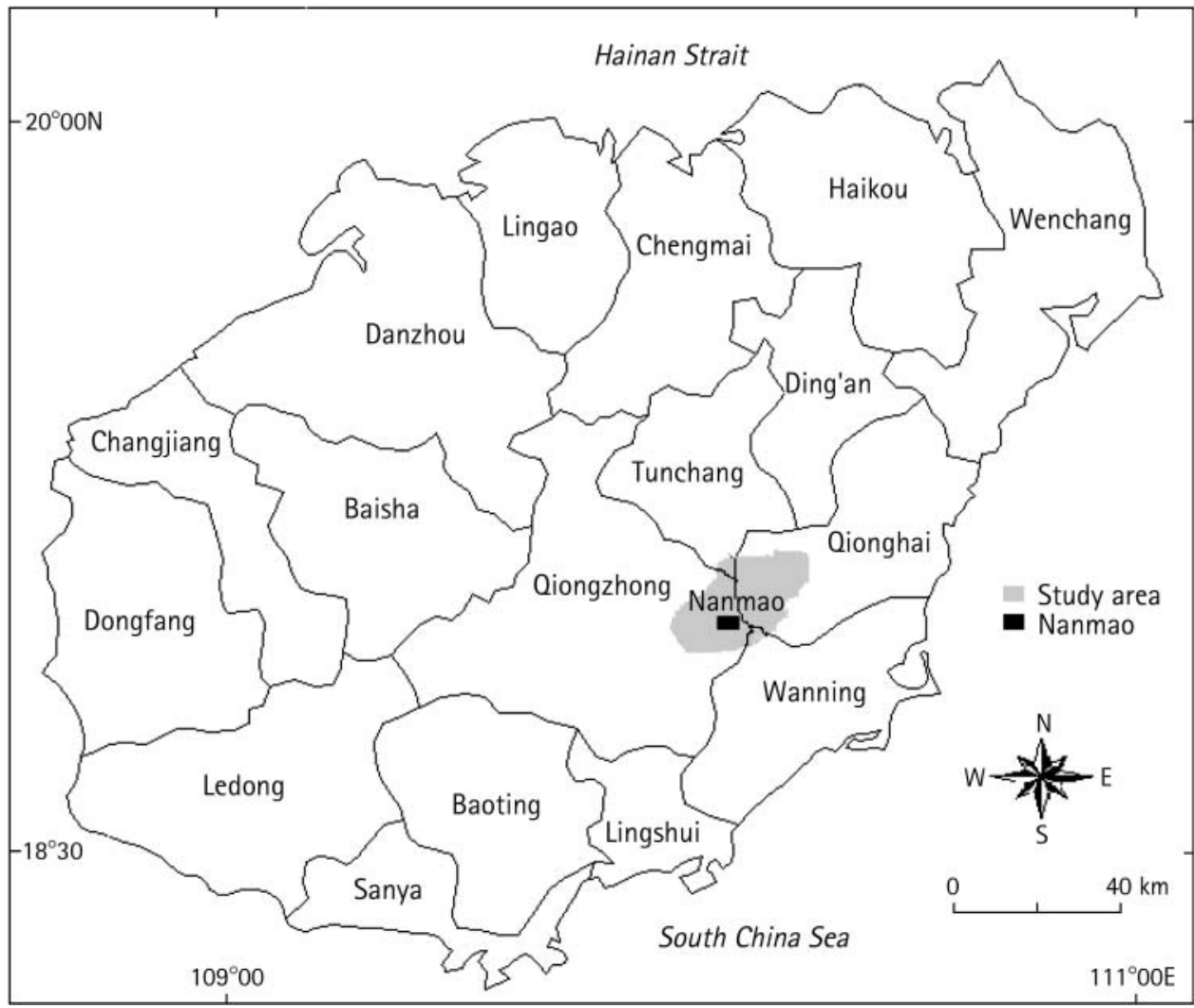

Fig. 1 The location of the study site, Nanmao and surrounding areas (shaded), on Hainan Island.

group. The vegetation consists primarily of monsoon rainforest, rubber plantation and rice fields. In the past few decades much of the rainforest has been destroyed through human activity and now exists as secondary forest and shrub (Gong et al., 2003a).

\section{Materials and methods}

We visited markets and turtle collectors once per week for 23 weeks from 20 February to 15 August 2003 to gather information on the turtle trade in Nanmao and surrounding villages. To prevent the double-counting of turtles in villages and markets we measured and recorded the length and width of carapace and plastron, length of tail, body weight, sex and location in the market of each turtle. By comparing data we thus avoided the double-counting of turtles.

Surveying illegal trade and collection of turtles is difficult because these activities are secretive. Even turtle traders in the markets were reluctant to share information with us because of their suspicions that we were policemen. As a result, little information was collected during the first 2 months. Gradually we were able to befriend some local villagers who were willing to share information for a fee. They also took us to see the turtles collected from the field and introduced us to some other turtle traders and collectors. It is in this way we were able to collect information on illegal turtle collecting and trade.

Questionnaire surveys were conducted from May to July 2003. The questionnaire was designed to gather information about the turtle trade and the opinions of the local people on turtles. A total of 196 interviewees were selected randomly from 1,200 local villagers in Nanmao, of which 14 questionnaires were invalid because of incompleteness, leaving us with 182 valid questionnaires. For the question regarding the turtle species found in the local area, a set of illustrations of the turtles of Hainan Province were shown to the interviewees.

\section{Results}

We found a total of 245 freshwater turtles belonging to eight species (Table 1). The collectors told us that these turtles were collected from Nanmao and surrounding areas. In addition, we believe that two turtle species not recorded in our survey (Palea steindachneri and Pelochelys 
Table 1 Number of individual turtles of eight species found in the villages and markets of Nanmao and surrounding areas, the market price for each species, Chinese state-protected wildlife list status, Red List category (IUCN, 2006), and listing on CITES Appendices (CITES, 2005).

\begin{tabular}{|c|c|c|c|c|c|c|}
\hline \multirow[b]{2}{*}{ Species } & \multicolumn{2}{|c|}{ Number of individuals } & \multirow{2}{*}{$\begin{array}{l}\text { Market price } \\
\left(\mathrm{USD}_{\mathrm{kg}}{ }^{-1}\right)\end{array}$} & \multirow{2}{*}{$\begin{array}{l}\text { State-protected } \\
\text { wildlife status }\end{array}$} & \multirow{2}{*}{$\begin{array}{l}\text { Red List } \\
\text { category* }\end{array}$} & \multirow{2}{*}{$\begin{array}{l}\text { CITES } \\
\text { Appendix }\end{array}$} \\
\hline & From villages & From markets & & & & \\
\hline Platysternon megacephalum & 6 & 0 & 30 & & EN & II \\
\hline Cuora galbinifrons & 37 & 24 & 20 & & CR & II \\
\hline Cuora trifasciata & 1 & 0 & 2,000 & Grade II & CR & II \\
\hline Pyxidea mouhotii & 87 & 49 & 18 & & EN & II \\
\hline Sacalia quadriocellata & 20 & 5 & 10 & & EN & III \\
\hline Geoemyda spengleri & 8 & 3 & 20 & Grade II & EN & III \\
\hline Mauremys mutica & 1 & 0 & 140 & & EN & II \\
\hline Pelodiscus sinensis & 0 & 4 & 20 & & VU & III \\
\hline
\end{tabular}

${ }^{*} \mathrm{CR}$, Critically Endangered; EN, Endangered; VU, Vulnerable

cantorii) may currently or historically have been found in Nanmao. Many villagers expressed familiarity with these species when shown illustrations of them, and some local turtle collectors told us these species were found in the past but are now rare because of over-collecting.

Illegal trade and collecting of turtles is widespread. In Nanmao and surrounding areas we found $>20$ small illegal turtle purchasing stations and black markets. Of the 245 turtles found (106 female, 67 male and 72 unsexed juveniles), 160 were for sale in Nanmao village, and the others in the illegal turtle purchasing stations and black markets. We received information from villagers about when turtles were captured but we were not able to see all of the turtles because they were often sold before we arrived. We therefore believe that 245 is an underestimate of the number of turtles sold during the 8 months of our study. Turtles are a valuable commodity in Nanmao, with market prices of USD $10-2,000 \mathrm{~kg}^{-1}$ (Table 1). Turtle collecting seems to be undiscerning as all turtle species, regardless of age and sex, were seen for sale in the markets. A summary of the responses to the questionnaire are given in Table 2.

\section{Discussion}

Almost all of the villagers believe that turtles are a delicacy and that eating turtle can make them healthy and help them live longer (Table 2). However, it seems that the most important factor leading to the decline of turtle populations is not local consumption but the illegal turtle trade. Most captured freshwater turtles were sold rather than consumed locally. Income is low in Nanmao, with $78.6 \%$ of the villagers earning USD 200 per year or less (Table 2). This cannot meet all of people' needs, and the collection and sale of turtles is a useful income supplement.
There is a lack of local conservation awareness. Most people are uneducated, with $c .78 .6 \%$ of the villagers having attained only a primary level of education. More than $70 \%$ of the villagers do not understand why wildlife should be conserved and, as a result, few people protect wildlife voluntarily. Almost all of the villagers think that turtles are a public resource they have the right to collect and use for their own benefit and $>50 \%$ of the villagers who collect turtles do so despite knowing it is illegal. From the questionnaire we were able to determine that the main factors leading to illegal trade in turtles are a cultural tradition of turtle use, lack of conservation education, incentive for financial rewards and insufficient law enforcement.

It had been thought that the over-collecting of turtles throughout China had resulted in the extirpation of local populations (Shi et al., 2003) but data from the markets and questionnaires show that Nanmao still has a rich freshwater turtle fauna. However, illegal trade and collecting have had deleterious effects on these turtle populations and population densities are low (Gong et al., 2003a). Although China's Wild Animals Protection Law came into effect in 1989 (Jia \& Ma, 1991) and measures have recently been taken specifically to control illegal trade in turtles (Meng et al., 2002), these efforts appear to have been ineffective.

Although areas have been set aside as nature reserves, illegal collecting still occurs in these reserves and there is little law enforcement (deBruin \& Artner, 1999; Gong et al., 2005a). The main factors that allow poaching to persist in nature reserves are: (1) the lack of information on species present and their distribution, (2) too few law enforcement agents patrolling the area, (3) difficult working conditions and low salary providing little motivation for these agents, and (4) no effective assessment system to check the results of conservation actions (Gong et al., 2005a). The Wild Animals Protection Law seems to be ineffective in preventing poaching in 
Table 2 Questions asked and the villagers' answers. The frequency of each answer is shown, as are the percentages of respondents for each answer.

\begin{tabular}{|c|c|c|}
\hline Question & Answer & Frequency $(\%)$ \\
\hline \multirow[t]{2}{*}{ Have you ever eaten turtles? } & Yes & $122(67.0)$ \\
\hline & No & $60(33.0)$ \\
\hline \multirow{2}{*}{$\begin{array}{l}\text { Do you believe that turtles are a delicacy \& that eating turtles can make you } \\
\text { healthy \& help you live longer? }\end{array}$} & Yes & $176(96.7)$ \\
\hline & No & $6(3.3)$ \\
\hline \multirow{2}{*}{ Have you ever poached wild turtles? } & Yes & $113(62.1)$ \\
\hline & No & $69(37.9)$ \\
\hline \multirow[t]{3}{*}{ What is your purpose if you poach wild turtles? } & For food \& medicine & $17(15.0)$ \\
\hline & For sale & $94(83.2)$ \\
\hline & To keep as pets & $2(1.8)$ \\
\hline \multirow[t]{2}{*}{ If you are a turtle collector, what is the trend of wild turtle populations? } & Declining & $113(100.0)$ \\
\hline & Stable or increasing & $0(0.0)$ \\
\hline \multirow[t]{2}{*}{ Do you think wild turtles should be protected? } & Yes & $16(8.8)$ \\
\hline & No & $166(91.2)$ \\
\hline \multirow[t]{2}{*}{ If you are a turtle collector, do you know that poaching wild turtles is illegal? } & Yes & $82(72.6)$ \\
\hline & No & $31(27.4)$ \\
\hline \multirow{2}{*}{$\begin{array}{l}\text { Do you know whether there is law enforcement to prevent illegal turtle } \\
\text { poaching \& trade in Nanmao? }\end{array}$} & Yes & $37(20.3)$ \\
\hline & No & $145(79.7)$ \\
\hline \multirow[t]{2}{*}{ Do you know why wild turtles are protected by China's Wild Animals Protection Law? } & Yes & $46(25.3)$ \\
\hline & No & $136(74.7)$ \\
\hline \multirow[t]{3}{*}{ What is your education level? } & Primary or lower & $143(78.6)$ \\
\hline & Junior or senior & $37(20.3)$ \\
\hline & Higher & $2(1.1)$ \\
\hline \multirow[t]{3}{*}{ What are the sources of your family income? } & Agriculture & $82(45.0)$ \\
\hline & Agriculture \& poaching & $94(51.7)$ \\
\hline & Commerce or others & $6(3.3)$ \\
\hline \multirow[t]{3}{*}{ What is the per capita mean annual income of your family over the last 5 years? } & $<$ USD 200 & $143(78.6)$ \\
\hline & USD 200-400 & $32(17.6)$ \\
\hline & $>$ USD 400 & $7(3.8)$ \\
\hline
\end{tabular}

Nanmao. Priority should be given to enhancing law enforcement as well as adding all native freshwater turtle species to the state-protected species list and CITES Appendix I (Table 1). Currently, only four of Hainan Province's 12 native freshwater turtle species are listed on the state-protected wildlife list (C. trifasciata, Geoemyda spengleri and P. steindachneri in grade II, and $P$. cantorii in grade I). In addition, more funding and manpower is necessary to train law enforcement agents effectively and enforce legislation.

In Nanmao most people have little formal education and they feel it is their right to collect turtles for personal use. Actions needs to be taken to increase public awareness of conservation. Educational programmes in rural areas, especially for children, may help to change cultural beliefs and place focus on the importance of conservation. Cities, where the majority of demand occurs, should also be targeted with awareness programmes to curb turtle consumption. It is important that all levels of organization, from national governments and international organizations to local governments and schools, cooperate in raising conservation awareness. Turtles have such a long history of use that it is unrealistic to imagine that education will completely eliminate their collection. In addition, alternatives should be considered to improve income and provide incentives for villagers to protect turtles, such as reducing agriculture taxes and subsidizing education.

Based on the data collected we believe that the freshwater turtle fauna of Nanmao comprises at least eight of the 12 freshwater turtle species known from Hainan Island. Further surveys are required to assess fully the other species. We believe that the most effective action to protect the remaining turtle populations and their habitat is to establish a nature reserve with appropriate law enforcement (Gong et al., 2003b). At present, there are only two nature reserves in China (in Guangdong and Fujian provinces) created to protect the large rivers and lakes in which $P$. cantorii is found. However, most freshwater turtles live in small montane rivers and streams. A particular problem facing conservation in China relates to governmental jurisdiction: the management of aquatic wildlife, including freshwater turtles, is overseen by the Fisheries department, while the mountainous areas where most freshwater turtles live are managed by the Forest Department. In addition, each department has central and provincial 
Table 3 List of other threatened vertebrates found during turtle surveys in the Nanmao area, with details of their protection status at either a state or provincial level.

\begin{tabular}{|c|c|}
\hline Species & Protection status \\
\hline $\begin{array}{l}\text { Burmese python Python } \\
\text { molurus bivittatus }\end{array}$ & State-protected wildlife grade I \\
\hline $\begin{array}{l}\text { Hainan hill partridge } \\
\text { Arborophila ardens }\end{array}$ & State-protected wildlife grade I \\
\hline $\begin{array}{l}\text { Grey peacock pheasant } \\
\text { Polyplectron katsumatae }\end{array}$ & State-protected wildlife grade I \\
\hline $\begin{array}{l}\text { Silver pheasant Lophura } \\
\text { nycthemera }\end{array}$ & State-protected wildlife grade II \\
\hline $\begin{array}{l}\text { Southern crow pheasant } \\
\text { Centropus sinensis }\end{array}$ & State-protected wildlife grade II \\
\hline $\begin{array}{l}\text { Chinese pangolin Manis } \\
\text { pentadactyla }\end{array}$ & State-protected wildlife grade II \\
\hline Chinese cobra Naja atra & Hainan Province protected wildlife \\
\hline $\begin{array}{l}\text { King cobra Ophiophagus } \\
\text { hannah }\end{array}$ & Hainan Province protected wildlife \\
\hline $\begin{array}{l}\text { Chinese francolin } \\
\text { Francolinus pintadeanus }\end{array}$ & Hainan Province protected wildlife \\
\hline $\begin{array}{l}\text { Red giant flying squirrel } \\
\text { Petaurista hainana }\end{array}$ & Hainan Province protected wildlife \\
\hline Wild pig Sus scrofa & Hainan Province protected wildlife \\
\hline $\begin{array}{l}\text { Barking deer Muntiacus } \\
\text { muntjak }\end{array}$ & Hainan Province protected wildlife \\
\hline
\end{tabular}

divisions, further complicating the responsibility of management.

Setting aside a nature reserve to protect freshwater turtles will also benefit other species. The mountains of Nanmao are also the habitat of many other stateprotected wildlife grade I or grade II species (Table 3). We found all of the species listed in Table 3 in Nanmao village, where we were told these animals were collected locally. The major threats to these species are similar to the threats facing freshwater turtles, i.e. over-collecting and illegal trade.

The information we have collected will be submitted to the Hainan Provincial Forest Department to begin a dialogue on how to conserve these turtle species. We have organized some educational programmes in the Nanmao area, including publicizing China's Wild Animals Protection Law in villages and giving conservation awareness talks in local schools. Our future research will concentrate on further surveys of wild turtle species and other wildlife in the Nanmao area.

\section{Acknowledgements}

The authors would like to thank $\mathrm{Hu}$ Yunfang, the head of Nanmao village, for his support during the survey. Patrick Lynch, Wang Lijun, Jonathan Fong and James Ford Parham provided helpful suggestions that improved the manuscript. This work was supported financially by the National Science Foundation of China (No. 30260019) and the Kadoorie Farm and Botanic Garden, Hong Kong, China.

\section{References}

Ades, G., Banks, C.B., Buhlmann, K.A., Chan, B., Chang, H.C., Chen, T.H., Crow, R., Haupt, H., Kan, R., Lai, J.Y., Lau, M., Lin, H.C. \& Shi, H. (2000) Turtle trade in northeast Asia: regional summary. Chelonian Research Monographs, 2, 52-54.

Compton, J. (2000) An overview of Asian turtle trade. Chelonian Research Monographs, 2, 24-29.

CITES (2005) 2005 CITES Appendix. Http://www.cites.org/ eng/append/index.shtml [accessed 16 May 2006].

DeBruin, R.W.F. \& Artner, H.G. (1999) On the turtles of Hainan Island, Southern China. Chelonian Conservation and Biology, 3, 479-486.

Dalton, R. (2003) Mock turtles. Nature, 423, 219-220.

Gong, S.P. (2003) Investigation of freshwater turtles on Hainan Island. China Nature, 1, 36-37. [in Chinese]

Gong, S.P., Wang, J.C. \& Fu, B.L. (2003a) Why is the Wildlife Protection Law useless here? Chinese Wildlife, 6, 39-40. [in Chinese]

Gong, S.P., Xu, R.M. \& Shi, H.T. (2003b) Zoogeography and conservation priority of hard-shelled freshwater turtles on Hainan Island. Chinese Journal of Zoology, 6, 72-75. [in Chinese with English abstract]

Gong, S.P., Fu, Y.L., Wang, J.C., Shi, H.T. \& Xu, R.M. (2005a) Freshwater turtle trade in Hainan and suggestions for effective management. Biodiversity Science, 13, 239-247. [in Chinese with English abstract]

Gong, S.P., Shi, H.T., Xie, C.J., Chen, C. \& Xu, R.M. (2005b) Spring habitat selection by four eye-spotted turtle (Sacalia quadriocellata) in Limu Mountain of Hainan Island. Zoological Research, 2, 142-146. [in Chinese with English abstract]

IUCN (2006) 2006 IUCN Red List of Threatened Species. IUCN, Gland, Switzerland [http://www.redlist.org, accessed 15 June 2006].

Jia, J.B. \& Ma, J.Z. (1991) Management of Wildlife. Northeast Forest University Press, Harbin, China. [in Chinese]

Lau, M. \& Shi, H.T. (2000) Conservation and trade of terrestrial and freshwater turtles and tortoises in the People's Republic of China. Chelonian Research Monographs, 2, 30-38.

Meng, X., Zhou, Z. \& Stuart, B.L. (2002) Recent actions by the People' Republic of China to better control international trade of turtles. Turtle and Tortoise Newsletter, 5, 15-16.

Parham, J.F., Simison, W.B., Kozak, K.H., Feldman, C.R. \& Shi, H.T. (2001) New Chinese turtles: endangered or invalid? A reassessment of two species using mitochondrial DNA, allozyme electrophoresis and known-locality specimens. Animal Conservation, 4, 357-367.

Shi, H.T., Lau, M. \& Parham, J.F. (2003) Reports on the problems of China' turtles. China Nature, 1, 37. [in Chinese]

Shi, H.T. (2004a) Observations of wildlife trade in Wenchang City, Hainan Island, China. Turtle and Tortoise Newsletter, 8, 12-13.

Shi, H.T. (2004b) The fate of a wild caught Golden Coin Turtle (Cuora trifasciata) on Hainan Island, China. Turtle and Tortoise Newsletter, 8, 14-16.

van Dijk, P.P. (2000) The status of turtles in Asia. Chelonian Research Monographs, 2, 15-23.

Zhang, M.W., Zong, Y. \& Ma, J.F. (1998) Fauna Sinica, Reptilia Vol I. Science Press, Beijing, China. [in Chinese] 
Zhao, E.M. (1998) China Red Data Book of Endangered Animals: Amphibia and Reptilia. Science Press, Beijing, China. [in Chinese]

Zhao, E.M., Chang, H.W., Zhao, H. \& Adler, K. (2000) Revised checklist of Chinese Amphibia and Reptilia. Sichuan Journal of Zoology, 19, 196-207. [in Chinese]

\section{Biographical sketches}

Gong Shiping is interested in the study of population ecology and conservation of endangered animals, especially turtles in China.

Wang Jichao studies the population ecology and conservation of freshwater turtles in Hainan.

Shi Haitao is interested in the study and protection of turtles in China. He established the first Turtle Study Team to improve the study and conservation of turtles in China. His current interests are the ecology, captive breeding and conservation of threatened turtles of China.

Song Riheng studies the conservation of freshwater turtles in Hainan.

Xu Rumei studies the population ecology of insects and his current interests are the biology of invasive organisms and metapopulation ecology. 